\title{
Enhancing the quality attributes of salad dressing by incorporating Gac aril as a biologically active ingredient
}

\author{
Aprimoramento dos atributos de qualidade de molho de salada pela incorporação de \\ Gac aril como ingrediente biologicamente ativo
}

\author{
Phisut Naknaen ${ }^{1 \star}$, Nuttanapat Chinnapitiwong', Peimika Kruayoo' \\ ${ }^{1}$ Srinakhainwirot University, Faculty of Agricultural Product Innovation and Technology, Division of Food Science and Nutrition, Wattana/Bangkok - Thailand
}

\section{${ }^{*}$ Corresponding Author}

Phisut Naknaen, Srinakhainwirot University, Faculty of Agricultural Product Innovation and Technology, Division of Food Science and Nutrition, 114 Sukhumvit 23, Wattana/Bangkok 10110 - Thailand, e-mail: phisut@g.swu.ac.th

Cite as: Enhancing the quality attributes of salad dressing by incorporating Gac aril as a biologically active ingredient. Braz. J. Food Technol., v. 21, e2017129, 2018

Received: Aug. 15, 2017; Accepted: Mar. 20, 2018

\section{Abstract}

Gac aril (GA) contains a very high level of lycopene, giving it exceptional antioxidant properties. Based on the superior properties of GA, the aim of this work was to fortify salad dressings with the lycopene from GA and monitor their stability during storage. The salad dressings were produced by incorporating different amounts of GA ( $0 \%$ to $20 \%, g / 100 \mathrm{~g})$ in the formulations. An increase in GA content caused a marked increase in the soluble fibre, lycopene and total phenolic contents while the fat content and the caloric value decreased. The firmness and viscosity also decreased with increasing GA content. The sensory evaluation revealed that the GA could be added to salad dressings up to a level of $20 \%$ and still be accepted by the consumer. It was verified the GA antioxidant effect in the salad dressing compared to that in the sample without GA, as evidenced by the peroxide value (POV), thiobarbituric acid-reactive substances (TBARS), $p$-anisidine value ( $p$-AV) and total oxidation value (Totox $\mathrm{V}$ ). The protective effects were approximately $1.75,2.58,5.14$ and 7.58 times higher than those in the control sample for the samples containing 5\%,10\%,15\% and $20 \% \mathrm{GA}$, respectively. It was concluded that GA could be used as an alternative source of lycopene, polyphenol compounds and dietary fibre, to enrich salad dressings. This work could be used as a guideline for industry to develop high value-added salad dressings.

Keywords: Gac aril; Salad dressing; Lycopene; Antioxidant; Lipid oxidation; Quality.

\section{Resumo}

Gac aril (GA) contém um alto nível de licopeno, conferindo-lhe propriedades antioxidantes excepcionais. Baseado nas propriedades superiores de GA, o objetivo deste trabalho foi fortificar molhos de salada com o licopeno de GA, além de monitorar a estabilidade dos molhos durante a estocagem. Os molhos de salada foram produzidos incorporando diferentes quantidades de GA ( $0 \%$ a 20\%, g/100 g) nas formulações. Um aumento na quantidade de GA causou aumentos marcantes nos conteúdos de fibra solúvel, licopeno e compostos fenólicos totais, enquanto o conteúdo de gordura e o valor calórico diminuíram. A firmeza e a viscosidade também diminuíram com aumento no conteúdo de GA. A avaliação sensorial revelou que o GA pode ser acrescentado aos molhos de salada até um nível de $20 \%$, mantendo a aceitação do produto pelo consumidor. Verificou-se o efeito antioxidante do GA no molho de salada comparativamente ao produto sem GA, evidenciado pelo valor de peróxido (POV), substâncias reativas ao ácido tiobarbitúrico (TBARS), valor de p-anisidina (p-AV) e valor total de oxidação (Totox V). Os efeitos de proteção foram aproximadamente 1,75; 2,58; 5,14 e 7,58 vezes mais altos nas amostras contendo 5\%, 10\%, 15\% e 20\% de GA, respectivamente, quando comparados com o valor na amostra de controle. Concluiu-se que GA pode ser usado como uma fonte alternativa de licopeno, compostos fenólicos e fibra alimentar, para enriquecer os molhos de salada. Este trabalho podia ser usado como diretriz para indústria, para desenvolver molhos de salada com alto valor agregado.

Palavras-chave: Gac aril; Molhos de salada; Licopeno; Antioxidante; Oxidação lipídica; Qualidade. 


\section{Introduction}

The Gac fruit (Momordica cochinchinensis Spreng) is one of the traditional fruits grown in Southeast Asia, especially in Thailand and Vietnam. In addition, Gac aril (GA) contains high levels of carotenoids, particularly lycopene, which is well known to be beneficial to human health (KUBOLA; SIRIAMORNPUN, 2011). Several researchers reported that lycopene has been shown to possess powerful health-enhancing properties, such as antioxidant and anti-carcinogenic activities (KELKEL et al., 2011; SIWACH et al., 2016). The lycopene content of GA is much higher than the lycopene content usually found in tomato, and it has been reported that GA has approximately 16 times the lycopene found in tomato (VUONG et al., 2006). In addition, GA is considered to be a source of phenolic phytochemicals (KUBOLA; SIRIAMORNPUN, 2011). Thus the incorporation of $G A$ into food products could not only enhance product appeal, but also prevent the quality loss caused by lipid oxidation.

Salad dressing is one of the most popular basic sauces in the world. This product has received growing attention in the food industry due to increased consumer demand for salads as a healthy food option (MELO et al., 2015). However, salad dressing is susceptible to deterioration due to auto-oxidation. Natural antioxidants such as polyphenols and plant pigments are preferred to synthetic antioxidants because they are safer than the synthetic ones, and they present an equivalent ability to prevent lipid oxidation (LI et al., 2014). Currently, the use of GA as an active ingredient in real food systems, particularly in salad dressing, is rarely reported. Thus the aim of this study was to evaluate the feasibility of incorporating GA as a source of lycopene, dietary fibre and polyphenol in salad dressing to enhance its nutritional composition and improve the storage stability.

\section{Material and methods}

\subsection{Raw materials and salad dressing preparation}

Fresh Gac fruits were purchased from a local market in Talad Thai, Pathum Thani, Thailand. The fruits were transported in an insulated hard plastic container to avoid light and temperature exposure during transport, and used on the same day. The red aril surrounding the seeds was completely separated and used to incorporate into the salad dressing. The salad dressing formulation consisted of the following ingredients (g/100 g): soybean oil (40 g/100 g), egg yolk (16 g/100 g), vinegar $(8.5 \mathrm{~g} / 100 \mathrm{~g})$, mustard (2 g/100 g), sugar (31 g/100 g) and salt ( $2.5 \mathrm{~g} / 100 \mathrm{~g})$. All the ingredients used were purchased from a local supermarket. For each preparation, one batch $(1 \mathrm{~kg})$ of salad dressing was produced. The sample preparation was as follows: the egg yolk and vinegar were first mixed together; then all the other ingredients, except the oil, were added and homogenised in a blender. Finally, the oil was added dropwise while mixing. For the samples fortified with GA, the following amounts of GA were added to the aqueous phase: $5 \%$, $10 \%, 15 \%$ and $20 \%(\mathrm{~g} / 100 \mathrm{~g})$, which were referred to as GA5\%, GA10\%, GA15\% and GA20\%, and the oil was then slowly added to the aqueous phase. The sample without GA (GA0\%) was used as the control sample. Immediately after production, all samples were pasteurized at $80{ }^{\circ} \mathrm{C}$ for 2 min and then aseptically packed in the transparent glass bottles. All samples were analysed for their proximate compositions, $\mathrm{pH}$, lycopene content, total phenolic content (TPC), redness, texture, viscosity and sensory evaluation within one day of production. In addition, each sample was stored at ambient temperature $\left(30^{\circ} \mathrm{C}\right)$ for 4 weeks and analysed every week. The above-mentioned properties, with the exception of the proximate composition and $\mathrm{pH}$, were monitored during storage. In addition, the peroxide value (POV), para-anisidine value ( $\mathrm{p}-\mathrm{AV})$, thiobarbituric acid-reactive substances (TBARS) and total oxidation value (Totox V) were also analysed.

\subsection{Determination of the proximate composition and $\mathrm{pH}$ value}

The proximate composition (moisture, lipid, protein and ash) of the salad dressings was determined in accordance with AOAC (LATIMER JUNIOR, 2012). The total dietary fibre (TF) and insoluble dietary fibre (IF) were analysed using the total dietary fibre assay kit obtained from Sigma-Aldrich, and the soluble dietary fibre (SF) content was calculated by subtracting the IF from the TF. The $\mathrm{pH}$ value was obtained using a $\mathrm{pH}$-meter.

\subsection{Sensory evaluation}

A sensory evaluation based on a 9-point hedonic scale was carried out. Each sample was served and the 50 untrained panellists were asked to score the sensory characteristics (colour, texture, viscosity, flavour and overall acceptability). Each sample was labelled with a random 3-digit code and the serving order was also completely randomized. Water was provided to rinse the palate between samples. The sensory evaluation was carried out in a testing area with properly controlled environmental conditions.

\subsection{Determination of the lycopene content}

The lycopene was extracted using the method of Kubola and Siriamornpun (2011) with slight modifications. A sample $(5 \mathrm{~g})$ was extracted with $20 \mathrm{~mL}$ of extraction solvent (hexane/acetone/ethanol: 50:25:25 v/v/v) for $30 \mathrm{~min}$ with magnetic stirring in a beaker covered with aluminium foil. Before incubating, nitrogen gas was blown over the solvent surface for $3 \mathrm{~min}$ to eliminate the oxygen gas. After incubation, $15 \mathrm{~mL}$ of water were added. The upper layer was collected and the lower phase was re-extracted 
Enhancing the quality attributes of salad dressing by incorporating Gac aril as a biologically active ingredient Naknaen, $P$. et al.

until a colourless state was obtained. The combined upper phase was then evaporated to dryness. The residue was dissolved in chloroform to a final volume of $4 \mathrm{~mL}$. The final solution was filtered through a $0.45 \mu \mathrm{m}$ membrane filter before injecting $(20 \mu \mathrm{L})$ into a high performance liquid chromatography (HPLC). The method of Kha et al. (2013) was applied with some modifications to analyse the lycopene. The HPLC analysis (HPLC; Model: Agilent 1100 series, Agilent, Santa Clara, CA, USA) was carried out using a C18 LUNA column $(4.6 \mathrm{~mm} \times 250 \mathrm{~mm}, 5 \mu \mathrm{m}$, Phenomenex) at a flow rate of $1 \mathrm{~mL} / \mathrm{min}$. The mobile phase consisted of acetonitrile, dichloromethane and methanol (5: $4: 1 \mathrm{v} / \mathrm{v} / \mathrm{v})$, containing $0.1 \%$ butylated hydroxyl toluene (BHT). The lycopene content was detected at $450 \mathrm{~nm}$. The lycopene was quantified using an external standard curve and expressed as $\mu \mathrm{g}$ per g sample (dry basis).

\subsection{Determination of the Total Phenolic Compound (TPC) content}

All samples (2 g) were extracted using $70 \%$ acetone $(30 \mathrm{~mL})$ for $30 \mathrm{~min}$. The mixture was then centrifuged at $1000 \times g$ for $10 \mathrm{~min}$ and the supernatant collected for the TPC analysis. The TPC content was determined by the reaction using the Folin-Ciocalteau reagent. Gallic acid was used as the standard and the TPC content expressed as mg gallic acid equivalent (GAE) per g sample (dry basis) (TSENG; ZHAO, 2013).

\subsection{Determination of the redness, firmness and viscosity}

The redness was measured using a colorimeter (Colorflex, Hunter Lab. Inc., USA) and reported in terms of the $a^{*}$ value. The texture was measured using a TA.XT2i texture analyser (Stable Micro Systems Ltd, Surrey, UK) under the conditions described by Worrasinchai et al. (2006). The viscosity was measured using the Rapid Visco Analyzer and recorded as centipoises (cp).

\subsection{Determination of the peroxide value (POV)}

A modified method of Shantha and Decker (1994) was applied to determine the peroxide value (POV). Initially, $0.3 \mathrm{~g}$ of each sample was extracted with $1.5 \mathrm{~mL}$ of isooctane/2-propanol $(3: 2, v / v)$, and centrifuged at $1000 \times g$ for $10 \mathrm{~min}$. In sequnce, $0.20 \mathrm{~mL}$ of the clear upper layer (isooctane as the blank) was added to the reagents consisting of $2.8 \mathrm{~mL}$ of methanol/1-butanol $(2: 1, \mathrm{v} / \mathrm{v}), 15 \mu \mathrm{L}$ of $3.94 \mathrm{M}$ ammonium thiocyanate solution and $15 \mu \mathrm{L}$ of $0.072 \mathrm{M}$ ferrous ion solution (freshly prepared from the supernatant by mixing an equal amount of $0.132 \mathrm{M} \mathrm{BaCl}_{2}$ and $0.144 \mathrm{M} \mathrm{FeSO}_{4}$ in $0.4 \mathrm{M} \mathrm{HCl}$ ), and then mixing well. The absorbance of the blood-red coloured solution was measured at $510 \mathrm{~nm}$ after incubation at room temperature for 20 min. A calibration curve of cumene hydroperoxide was prepared for the POV calculation and the results were expressed in term of mg cumene hydroperoxide equivalents/kg fat (dry weight basis).

\subsection{Determination of the Thiobarbituric Acid-Reactive Substances (TBARS)}

The thiobarbituric acid-reactive substances (TBARS) method was applied according to the method of Maqsood and Benjakul (2010). Each sample $(0.5 \mathrm{~g})$ was reacted with $2.5 \mathrm{~mL}$ of a TBA solution consisting of thiobarbituric acid $(0.375 \%)$, trichloroacetic acid (15\%) and $\mathrm{HCl}(0.25 \mathrm{~N})$. The mixture was boiled $\left(100{ }^{\circ} \mathrm{C}\right)$ for $10 \mathrm{~min}$ and then cooled under running tap water. The mixture was then sonicated for $30 \mathrm{~min}$ and centrifuged at $1000 \times \mathrm{g}$ for $10 \mathrm{~min}$. The intensity of the pink colour formed was detected at $532 \mathrm{~nm}$. The results were calculated using a standard curve prepared using 1,1,3,3-tetramethoxypropane (malonaldehyde; MAD) and expressed as mg of MAD equivalents/kg fat (dry weight basis).

\subsection{Determination of the $\mathrm{p}$-anisidine value}

The AOCS Official Method Cd 18-90 (FIRESTONE, 2009) was used to obtain the para-anisidine value ( $p-A V)$ with some minor modifications (O'KEEFE; PIKE, 2010). Initially each sample ( $2 \mathrm{~g}$ ) was added to a $25 \mathrm{~mL}$ volumetric flask and made up to volume with isooctane. After mixing, the sample was centrifuged at $1000 \times \mathrm{g}$ for $10 \mathrm{~min}$ and the upper layer collected to read the absorbance (A1) at $350 \mathrm{~nm}$ against isooctane as the blank. The upper layer or isooctane $(5 \mathrm{~mL})$ was then mixed well with the p-anisidine solution $(0.25 \%$ in glacial acetic acid, w/v) (1 mL). The absorbance (A2) was also read at $350 \mathrm{~nm}$ against isooctane containing $\mathrm{p}$-anisidine as the blank after incubation at room temperature for $10 \mathrm{~min}$. The p-AV was calculated using the equation described below and reported in term of $\mathrm{p}-\mathrm{AV} / \mathrm{g}$ fat (dry weight basis) (Equation 1).

$p-A V=25 \times[1.2 \times(A 2-A 1)] / 2$

\subsection{Determination of the total oxidation value and protective factor}

Both the POV and p-AV were used to calculate the total oxidation values (Totox V) as reported by Zou and Akoh (2013), using the following equation (Equation 2):

Totox $\mathrm{V}=2 \mathrm{POV}+\mathrm{p}-\mathrm{AV}$

The slope obtained from the regression analysis between Totox $V$ and the storage times of each sample was used to calculate the protective factor (PF). The protective factor (PF) was determined as the ratio of the slope between the control sample and the GA-treated sample. 


\subsection{Statistical analysis}

The experiment was carried out in two batches, and the measurements made in triplicate for each batch. The mean $\pm S D$ values were presented based on the six measurements obtained from the two batches (three measurements from each batch). The experimental data were subjected to an analysis of variance (ANOVA) and the differences between the means evaluated by Duncan's Multiple Range Test.

\section{Results and discussion}

\subsection{Proximate composition and $\mathrm{pH}$}

Table 1 shows the proximate compositions of the GA-added samples. A higher moisture content was found in all the GA-added samples compared to that of the control sample. In addition, the moisture content of the GA-added samples tended to increase with increasing levels of GA due to the high moisture content of the GA (approximately 80\%) (VUONG et al., 2006; SANGKASANYA et al., 2016). All the salad dressings fortified with GA contained lower protein and lipid contents than those of the control sample. The decrease in protein and fat contents induced by incorporating GA into the salad dressing could be attributed to changes in the total protein and fat contents in the formulation. The addition of less protein and fat content ingredients (GA) might be responsible for diluting the protein and fat contents of the salad dressing. In addition, a slight decrease in the ash content was observed when GA was added to the salad dressing. An apparent increase in the soluble fibre content was detected with increasing levels of GA in the formulation, while insoluble fibre was not found in any of the GA-added salad dressings. This result might be due to the inherent soluble fibre content of the GA used, which contributed to the soluble fibre content of the samples. The caloric values of the GA-added salad dressings decreased significantly with increasing levels of GA. In addition to water being the main component of GA, the GA is itself low in calories, since it contains soluble fibre, which is not digested in the human digestive tract. Hence, supplementing salad dressing with GA, which is rich in dietary fibre, could promote the salad dressing as a health product. According to Thai legislation, the minimum values necessary to identify a product as a source of dietary fibre are $2.5 \mathrm{~g}$ of fibre per $100 \mathrm{~g}$ of product. Therefore, the salad dressings produced with the addition of $5-20 \%$ GA could be classified as sources of dietary fibre. The $\mathrm{pH}$ values of all the GA-added salad dressings tended to be higher than that of the control sample, although no difference was detected between the $\mathrm{pH}$ value of the control sample and that of the sample with the addition of 5\% GA (Table 1). The increase in moisture content due to the addition of GA led to dilution of the acetic acid in the aqueous phase of the GA-added samples (WORRASINCHAl et al., 2006). Generally, the $\mathrm{pH}$ of salad dressings produced using

Table 1. Properties of salad dressing samples with the addition of various amounts $(0,5,10,15$ and $20 \%)$ of $\mathrm{GA}$

\begin{tabular}{|c|c|c|c|c|c|}
\hline Properties/Treatments & $0 \%$ GA & $5 \%$ GA & $10 \%$ GA & $15 \%$ GA & $20 \%$ GA \\
\hline \multicolumn{6}{|l|}{ Chemical composition } \\
\hline Fat $(\mathrm{g} / 100 \mathrm{~g})$ & $42.39 \pm 0.03^{a}$ & $34.82 \pm 0.77^{b}$ & $33.60 \pm 0.09^{b}$ & $31.71 \pm 0.51^{c}$ & $30.01 \pm 0.53^{c}$ \\
\hline Protein (g/100 g) & $1.80 \pm 0.01^{a}$ & $1.78 \pm 0.01^{\mathrm{ab}}$ & $1.74 \pm 0.05^{b}$ & $1.55 \pm 0.01^{c}$ & $1.66 \pm 0.04^{b}$ \\
\hline Ash (g/100 g) & $1.58 \pm 0.12^{\mathrm{a}}$ & $1.55 \pm 0.18^{\mathrm{ab}}$ & $1.42 \pm 0.14^{b}$ & $1.32 \pm 0.12^{c}$ & $1.24 \pm 0.28^{d}$ \\
\hline Soluble fibre (g/100 g) & $0.00 \pm 0.00^{e}$ & $2.72 \pm 0.41^{d}$ & $4.63 \pm 0.36^{c}$ & $7.68 \pm 0.53^{b}$ & $9.33 \pm 0.28^{a}$ \\
\hline Moisture (g/100 g) & $17.18 \pm 0.55^{d}$ & $22.61 \pm 0.32^{c}$ & $26.23 \pm 0.14^{b}$ & $28.11 \pm 0.40^{\mathrm{a}}$ & $29.88 \pm 0.28^{a}$ \\
\hline Caloric carbohydrate (g/100 g) & $37.05 \pm 0.49^{a}$ & $36.52 \pm 0.78^{b}$ & $32.38 \pm 0.11^{c}$ & $29.63 \pm 0.38^{d}$ & $27.88 \pm 0.16^{e}$ \\
\hline Total carbohydrate (g/100 g) & $37.05 \pm 0.49$ & $39.24 \pm 0.71^{d}$ & $37.01 \pm 0.66^{a}$ & $37.21 \pm 0.66^{a}$ & $37.21 \pm 0.31^{a}$ \\
\hline Calories (kcal/100 g) & 536.91 & 466.58 & 438.88 & 410.11 & 388.25 \\
\hline $\mathrm{pH}$ value & $3.45 \pm 0.05^{c}$ & $3.51 \pm 0.02^{c}$ & $3.59 \pm 0.02^{b}$ & $3.63 \pm 0.02^{\mathrm{ab}}$ & $3.67 \pm 0.01^{a}$ \\
\hline Lycopene content $(\mu \mathrm{g} / \mathrm{g})$ & $0.00 \pm 0.00^{e}$ & $210 \pm 2.65^{d}$ & $470 \pm 5.43^{c}$ & $690 \pm 3.88^{b}$ & $930 \pm 5.54^{a}$ \\
\hline Total phenolic content $(\mathrm{mg} / \mathrm{g})$ & $0.03 \pm 0.00^{e}$ & $0.39 \pm 0.06^{d}$ & $0.74 \pm 0.06^{c}$ & $1.06 \pm 0.07^{b}$ & $1.72 \pm 0.05^{a}$ \\
\hline \multicolumn{6}{|l|}{ Physical properties } \\
\hline$a^{*}$ & $2.04 \pm 0.15^{d}$ & $22.98 \pm 0.14^{c}$ & $29.51 \pm 0.14^{b}$ & $31.75 \pm 0.08^{\mathrm{ab}}$ & $32.06 \pm 0.61^{a}$ \\
\hline Firmness (g force) & $488.9 \pm 6.3^{a}$ & $371.7 \pm 4.6^{b}$ & $317.8 \pm 6.8^{c}$ & $252.0 \pm 5.6^{d}$ & $230.5 \pm 5.2^{\mathrm{e}}$ \\
\hline Viscosity (cP) & $4868 \pm 50^{a}$ & $3811 \pm 98^{b}$ & $3147 \pm 75^{c}$ & $2787 \pm 64^{d}$ & $2301 \pm 60^{e}$ \\
\hline \multicolumn{6}{|l|}{ Sensory evaluation } \\
\hline Colour & $7.17 \pm 1.05^{\mathrm{a}}$ & $7.34 \pm 1.02^{\mathrm{a}}$ & $7.31 \pm 1.02^{\mathrm{a}}$ & $6.80 \pm 1.02^{\mathrm{a}}$ & $6.98 \pm 1.01^{a}$ \\
\hline Texture & $6.69 \pm 1.53^{\mathrm{a}}$ & $7.26 \pm 0.82^{a}$ & $7.22 \pm 0.87^{a}$ & $7.31 \pm 1.05^{\mathrm{a}}$ & $7.23 \pm 0.91^{a}$ \\
\hline Viscosity & $6.34 \pm 1.22^{\mathrm{a}}$ & $6.89 \pm 1.18^{a}$ & $7.03 \pm 0.89^{a}$ & $7.06 \pm 1.03^{a}$ & $6.94 \pm 1.14^{\mathrm{a}}$ \\
\hline Flavour & $6.66 \pm 1.30^{\mathrm{a}}$ & $7.21 \pm 1.16^{a}$ & $7.17 \pm 1.01^{\mathrm{a}}$ & $7.11 \pm 1.13^{\mathrm{a}}$ & $6.83 \pm 1.10^{a}$ \\
\hline Overall acceptability & $6.97 \pm 1.15^{\mathrm{a}}$ & $7.26 \pm 0.82^{\mathrm{a}}$ & $7.34 \pm 0.87^{a}$ & $7.31 \pm 0.90^{\mathrm{a}}$ & $7.06 \pm 0.80^{\mathrm{a}}$ \\
\hline
\end{tabular}

Values followed by different letters in the same row are significantly different $(P<0.05)$. 
Enhancing the quality attributes of salad dressing by incorporating Gac aril as a biologically active ingredient Naknaen, $P$. et al.

unpasteurized egg should be less than 4.1 to reduce the risk of microbial growth during storage at ambient temperature for at least $24 \mathrm{~h}$ (RADFORD; BOARD, 1993). According to this theory, all the samples were stable during room temperature storage.

\subsection{Sensory evaluation}

The sensory qualities of the salad dressing samples were evaluated in terms of colour, texture, viscosity, flavour and overall acceptability, as shown in Table 1. No differences were found between the control sample and the samples containing 5-20\% GA for any of in the sensory attribute scores. This result indicated that an increase in redness and decrease in firmness and viscosity of the salad dressings due to the addition of GA was still accepted by the consumers, indicating that the sensory attributes of salad dressings containing GA are considered acceptable. Thus, the GA-added salad dressings with the incorporation of up to $20 \%$ GA were judged to be sensorially acceptable.

\subsection{Lycopene content and Total Phenolic Content (TPC) and their changes during storage}

It was found that the lycopene content apparently increased as the proportion of GA in the formulation increased $(p<0.05)$ (Table 1). In addition, it was found that the storage conditions investigated significantly affected the lycopene content of the salad dressing. A continuous decrease in lycopene content was found in all samples during storage (Figure 1a). Either oxidation or isomerization was responsible for the loss of lycopene, as reported by Anese et al. (2015) and Chen et al. (2009). According to these studies, the probable mechanism for carotenoid degradation is that the available oxygen in the presence of light promotes isomerization of trans-carotenoids to the cis-forms, which are less stable and more susceptible to degradation during storage. The current results are in agreement with the work of Shi et al. (2008) who reported that exposure to light caused a significant loss of lycopene from tomato puree during storage.

Increasing the level of GA in the salad dressings caused an increase in the TPC of the samples $(p<0.05)$
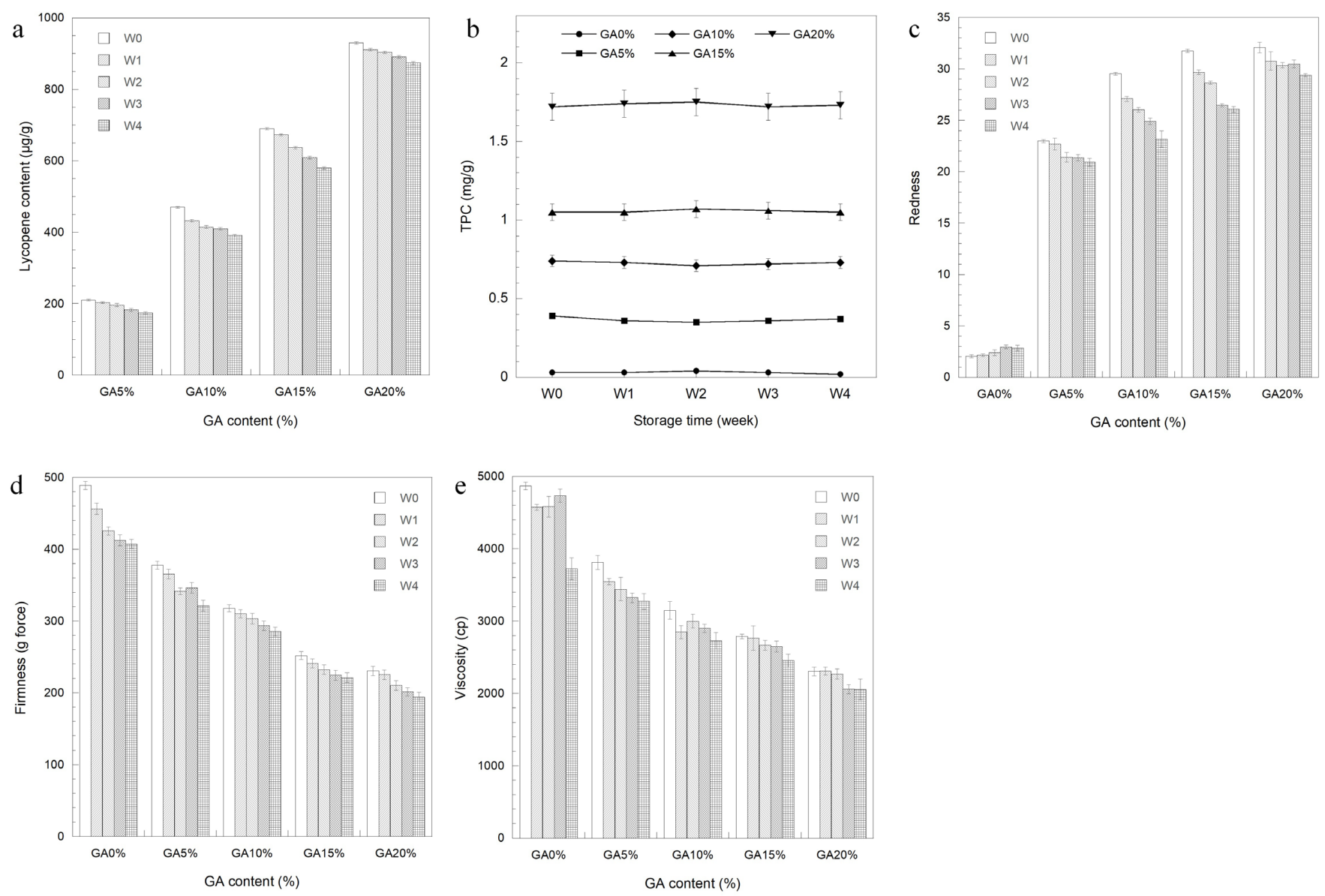

Figure 1. Change in lycopene content (a), TPC (b), redness (c), firmness (d) and viscosity (e) of salad dressing samples fortified with various amounts $(0,5,10,15$ and $20 \%)$ of GA during storage for 4 weeks. 
(Table 1). This result may be because GA is a greater source of phenolic compounds than the other ingredients in the formulation. Kubola and Siriamornpun (2011) reported that GA contained approximately $90 \mathrm{mg} / \mathrm{g}$ phenolic acid and the polyphenol compounds detected in GA were gallic acid, p-hydroxybenzoic acid, chlorogenic acid, caffeic acid, syringic acid, p-coumaric acid and ferulic acid. Thus it can be confirmed that the addition of GA to food products could enhance their phenolic compound contents and also improve their antioxidant capacities and health promoting properties. After 4 weeks of storage, there was no change in the TPC of any of the samples ( $p \geq 0.05$ ) (Figure $1 \mathrm{~b}$ ). This result indicated that the TPC in the samples was stable. Tseng and Zhao (2013) reported that no marked change was observed in the salad dressing with a $\mathrm{pH}$ value of 3.4 to 3.6, suggesting that the polyphenols tended to be stable under acidic conditions.

\subsection{Redness, textural characteristics and viscosity and their changes during storage}

The addition of GA to the formulation apparently influenced the colour of the salad dressing $(p<0.05)$ (Table 1). Compared with the control sample, all the samples containing GA presented higher values for $\mathrm{a}^{*}$, and increases in the GA content in the formulation caused greater increases in the redness. The increment in redness could be attributed to the typical red colour of GA caused by carotenoids, especially lycopene. In addition, redness could be used as an indicator of lycopene stability (SIWACH et al., 2016). A continuous decrease in the redness value was found during storage for all the GA-added samples (Figure 1c). This result was in agreement with the decrease in lycopene content described above. The decrease in redness can be explained by the degradation and isomerization caused by light exposure and oxygen availability during storage (SANTIPANICHWONG; SUPHANTHARIKA, 2007; SIWACH et al., 2016).

All the GA-added samples were less firm than the control sample. As the level of GA addition increased, so the firmness tended to decrease $(p<0.05)$ (Table 1$)$. The decrease in firmness induced by incorporating GA in the salad dressing can mainly be attributed to the high moisture content of the GA. In addition, increasing the proportion of GA in the formulation also decreased the apparent viscosity of the salad dressing $(p<0.05)$ (Table 1$)$. This may also be due to the high moisture content of the GA, causing a decrease in viscosity. In addition, both the firmness and viscosity of all the samples tended to decrease continuously during the 4 weeks of storage, as shown in Figures 1d, e. Both flocculation and coalescence of small droplets may take place, leading to the occurrence of the creaming process and consequent decline in firmness and viscosity during storage (WORRASINCHAI et al., 2006).

\subsection{Changes in POV, TBARS and p-AV during storage}

Fat auto-oxidation is a major problem in salad dressings and normally the primary lipid oxidation products can be measured in terms of the peroxide value (POV) (KISHK; ELSHESHETAWY, 2013). The POVs of all the samples containing GA were lower than that of the control sample (Figure 2a). An increase in POV was observed during the first 3 (for the control sample and the sample containing 5\% GA) and 2 (for the sample containing 10\% GA) weeks of storage. Thereafter, the POV tended to decrease for the control sample and that containing 5\% GA, while no marked change was detected for that containing $10 \%$ GA up to the end of storage. Decomposition of the hydroperoxide into the secondary oxidation products is generally responsible for the decrease in POV. A slight increase in the POV was found throughout storage in the samples containing $15 \%$ and $20 \%$ GA, suggesting that they were in a propagation stage, with a lower rate of hydroperoxide decomposition (MAQSOOD; BENJAKUL, 2010). Alamed et al. (2006) and McClements and Decker (2000) reported that the first products formed by oxidation are lipid hydroperoxides. These compounds, normally located at the droplet surface, could react with a transition metal from the aqueous phase, leading to the formation of highly reactive radicals such as peroxyl (ROO-) and alkoxyl (RO-), caused by decomposition of the lipid hydroperoxides $(\mathrm{ROOH})$. The unsaturated lipids, either located within oil droplets or at the interface of the O/W system, could react with the reactive radical as mentioned previously, leading to the propagation stage of lipid oxidation (ABUJA; ALBERTINI, 2001). As noted previously, the major antioxidant compounds in the salad dressings were lycopene and phenolic compounds. The greater the lycopene and phenolic compound contents, the greater the antioxidative effect found in terms retarding the formation of hydroperoxide, as evaluated by the POV. According to the results, the GA exhibited a significant antioxidant effect against primary oxidation in the salad dressings. There are several reports related to the ability of Iycopene to reduce photosensitized oxidation. This is due to its ability to quench singlet oxygen back to its less reactive triplet state. The singlet oxygen quenching ability of lycopene was two and ten times higher than those of $\beta$-carotene and $\alpha$-tocopherol, respectively. The 11 conjugated double bonds found in the lycopene structure can promote the ability to quench either oxygen or free radicals, resulting in the suppression of hydroperoxide formation (KELKEL et al., 2011; KONG; ISMAIL, 2011). In addition, the antioxidant activities that appeared in the GA-added samples were due to the phenolic compounds. Normally, phenolic compounds can act as chain-breaking antioxidants, hydroperoxide destroyers and metal chelators (KISHK; ELSHESHETAWY, 2013; CHONG et al., 2015). The hydroxyl groups linked to the aromatic ring of phenolic compounds 

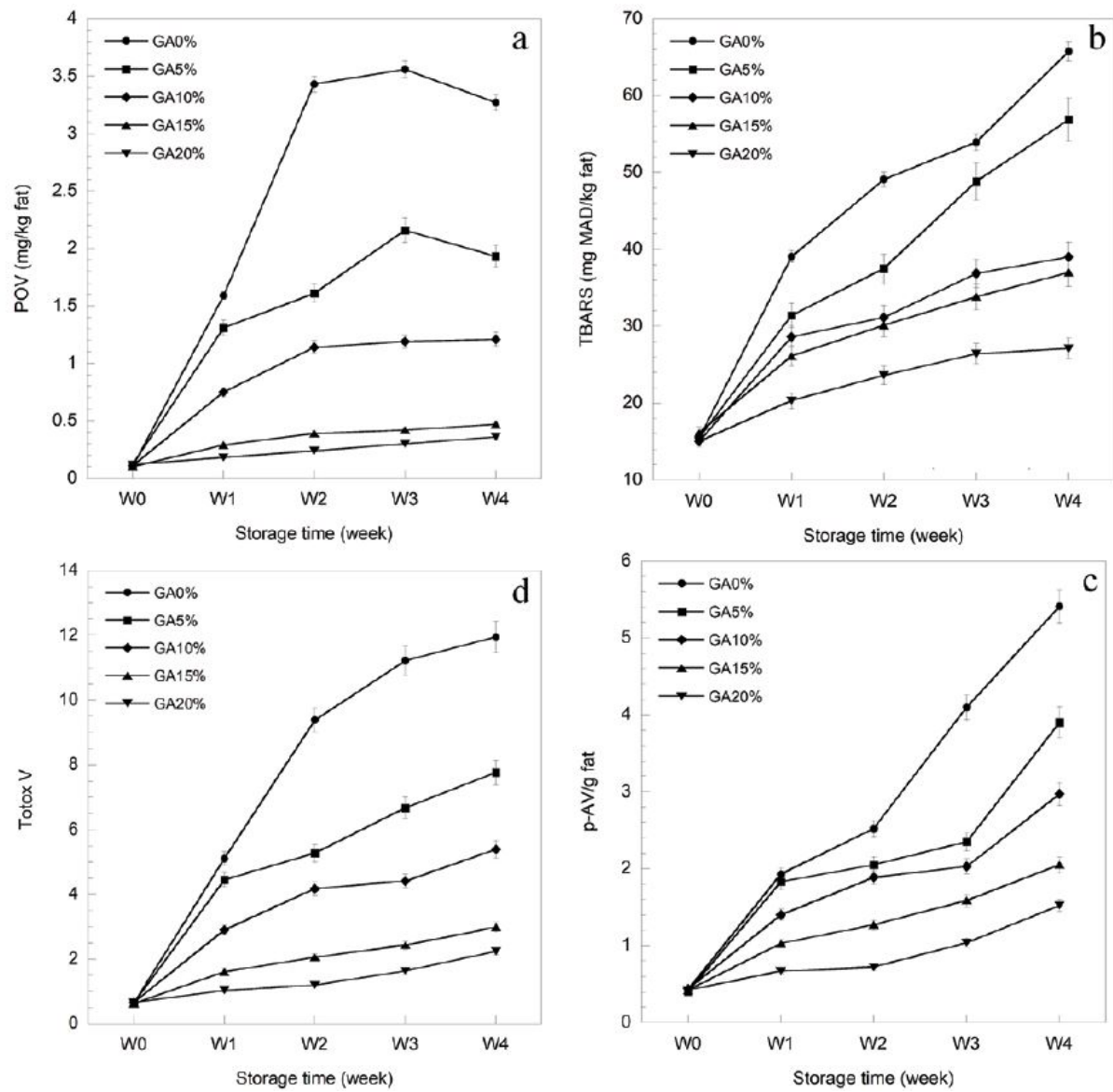

Figure 2. Change in POV (a), TBARS (b), p-AV (c) and Totox $V(d)$ of salad dressing samples fortified with various amounts $(0,5,10,15$ and $20 \%)$ of GA during storage for 4 weeks.

could donate hydrogen atoms with electrons to the free radicals, resulting in retardation of the propagation stage. Thus both lycopene and the phenolic compounds are able to prolong the propagation chain reaction during lipid oxidation processes in the salad dressings.

The TBARS determination is a common method to monitor the secondary products of lipid oxidation, mainly malonaldehyde. The TBARs assay is evaluated by the reaction of an aldehyde (malonaldehyde) with 2-thiobarbituric acid, while either non-volatile $\alpha$ - or $\beta$-unsaturated aldehydes are detected by the p-AV method (KWON et al., 2015). The TBARS levels tended to increase in all the samples during the 4 weeks of storage (Figure 2b). All the samples with added GA contained a lower TBARS than the control sample. The results indicated the efficient antioxidative activity of GA in salad dressing. A sharp increase in TBARS was found in both the control sample and the sample containing 5\% GA during the 4 weeks of storage, but it only gradually increased up to the end of storage in the samples with the addition of $10-20 \%$ GA. The results obtained from the TBARS confirmed that lycopene and the phenolic compounds effectively worked as antioxidant compounds to prevent further degradation of the hydroperoxide to more active oxidizing forms, such as malonaldehyde, in salad dressings in he presence of light. The results obtained for TBARs correlated well with the $\mathrm{p}$-AV values. The formation of secondary oxidation products caused by hydroperoxide decomposition was also measured by the p-AV (Figure 2c). Malonaldehyde and other short-chain carbon products of lipid oxidation are not stable and are decomposed to organic alcohols and acids, which are not determined by TBARS (MAQSOOD; BENJAKUL, 2010). The $\mathrm{p}-\mathrm{AV}$ of all the samples also tended to increase during the 4 weeks of storage, but those with the addition of $20 \%$ GA tended to exhibit the highest preventative effect and hence the addition of GA could reduce the production of these secondary oxidation products. Thus the ability of the lycopene and phenolic compounds to prevent lipid oxidation in the salad dressings varied according to the lycopene and phenolic compound contents.

\subsection{Changes in Totox $V$ and the Protective Factor (PF) during storage}

A comprehensive overview of oxidative deterioration could be assessed by the Totox $\mathrm{V}$. This value refers to both the primary and secondary oxidation products and 
Enhancing the quality attributes of salad dressing by incorporating Gac aril as a biologically active ingredient Naknaen, $P$. et al.

Table 2. Changes in the protective factor (PF) of salad dressing samples fortified with various amounts $(0,5,10,15$ and $20 \%)$ of GA during storage for 4 weeks.

\begin{tabular}{cccc} 
Treatments/Parameters & Slope & $\begin{array}{c}\text { Protective } \\
\text { factor (PF) }\end{array}$ & $\mathbf{R}^{2}$ \\
\hline 0\% GA & 2.88 & 1.00 & 0.92 \\
$5 \%$ GA & 1.65 & 1.75 & 0.91 \\
$10 \%$ GA & 1.01 & 2.85 & 0.91 \\
$15 \%$ GA & 0.56 & 5.14 & 0.96 \\
20\% GA & 0.38 & 7.58 & 0.96 \\
\hline
\end{tabular}

indicates the stability of fat based products against oxidative rancidity (KINDLEYSIDES et al., 2012; CHONG et al., 2015). Figure $2 d$ shows the changes in Totox $V$ during storage in the samples with and without the addition of GA. The Totox $V$ of all the samples increased with increasing storage time up to 4 weeks of storage. The Totox $V$ of the control sample was higher than that of the samples with added GA throughout storage. In addition, the oxidative stability of the salad dressings during storage increased with increasing amounts of added GA. The Totox $V$ increased sharply during storage for the samples containing $0 \%$ to $15 \% \mathrm{GA}$, as indicated by the slope $>1$, while only a gradual increase was found in the samples with the addition of $15 \%$ to $20 \%$ GA (slope $<1$ ) (Figure $2 d$ and Table 2). The results for Totox $V$ were coincidental with the protective factor (PF). The PF refers to the extent of progress of the oxidation process (KISHK; ELSHESHETAWY, 2013) as shown in Table 2. The highest Totox slope was found for the control sample, while a decrease in the Totox slope was observed with increasing levels of GA content. The reduction in the Totox slope caused an increase in $\mathrm{PF}$, confirming that the addition of GA could improve the stability to lipid oxidation of the samples during storage. According to the PF, the samples prepared by adding 5\% to $10 \%$ GA can retard lipid oxidation by approximately 1.75 and 2.58 , respectively, as compared to the control sample, while a stronger protective effect was observed in the samples containing $15 \%(P F=5.14)$ and $20 \%$ (PF $=7.58) \mathrm{GA}$.

\section{Conclusion}

This study demonstrated that GA can be used as an alternative source of antioxidant compounds to fortify salad dressings, not only increasing the lycopene, dietary fibre and polyphenol compound contents but also delaying lipid oxidation of the samples during storage. Based on the balance in physical, chemical and consumer acceptance, the best accepted product was the salad dressing fortified with $20 \% \mathrm{GA}$. However, the use of GA in salad dressings alters its original colour to a red colour, which could be an advantage to advise consumers that the food contains natural ingredients.

\section{Acknowledgements}

This study was carried out with the support of Srinakharinwirot University (Grant No. 745/2558). The authors also thank Prof. Dr. Anthony Gethin Hopkin for assistance with the English language.

\section{References}

ABUJA, P. M.; ALBERTINI, R. Methods for monitoring oxidative stress, lipid peroxidation and oxidation resistance of lipoproteins. Clinica Chimica Acta, v. 306, n. 1-2, p. 1-17, 2001. http://dx. doi. org/10.1016/S0009-8981(01)00393-X. PMid:11282089.

ALAMED, J.; MCCLEMENTS, D. J.; DECKER, E. A. Influence of of heat processing and calcium ion on the ability of EDTA to inhibit lipid oxidation in oil-in-water emulsions containing omega- 3 fatty acids. Food Chemistry, v. 95, n. 4, p. 585-590, 2006. http:// dx.doi.org/10.1016/j.foodchem.2005.01.041.

ANESE, M.; BOT, F.; PANOZZO, A.; MIROLO, G.; LIPPE, G. Effect of ultrasound treatment, oil addition and storage time on lycopene stability and in vitro bioaccessibility of tomato pulp. Food Chemistry, v. 172, p. 685-691, 2015. http://dx.doi.org/10.1016/j. foodchem.2014.09.140. PMid:25442608.

CHEN, J.; SHI, J.; XUE, S. J.; MA, Y. Comparison of lycopene stability in water-and oil-based food model systems under thermaland light-irradiation treatments. Lebensmittel-Wissenschaft + Technologie, v. 42, n. 3, p. 740-747, 2009. http://dx.doi. org/10.1016/j.Iwt.2008.10.002.

CHONG, Y. M.; CHANG, S. K.; SIA, W. C. M.; YIM, H. S. Antioxidant efficacy of mangosteen (Garcinia mangostana Linn.) peel extracts in sunflower oil during accelerated storage. Food Bioscience, $v$. 12, p. 18-25, 2015. http://dx.doi.org/10.1016/j.fbio.2015.07.002.

FIRESTONE, D. (Ed.). Official methods and recommended practice of the American Oil Chemists' Society: method Cd 18-90. Champaigon: AOCS, 2009.

KELKEL, M.; SCHUMACHER, M.; DICATO, M.; DIEDERICH, M. Antioxidant and anti-proliferative properties of lycopene. Free Radical Research, v. 45, n. 8, p. 925-940, 2011. http://dx.doi. org/10.3109/10715762.2011.564168. PMid:21615277.

KHA, T. C.; NGUYEN, M. H.; ROACH, P. D.; STATHOPOULOS, C. E. Effects of Gac aril microwave processing conditions on oil extraction efficiency, and -carotene and lycopene contents. Journal of Food Engineering, v. 117, n. 4, p. 486-491, 2013. http://dx.doi.org/10.1016/j.jfoodeng.2012.10.021.

KINDLEYSIDES, S.; QUEK, S.-Y.; MILLER, M. R. Inhibition of fish oil oxidation and the radical scavenging activity of New Zealand seaweed extracts. Food Chemistry, v. 133, n. 4, p. 1624-1631, 2012. http://dx.doi.org/10.1016/j.foodchem.2012.02.068.

KISHK, Y. F. M.; ELSHESHETAWY, H. E. Effect of ginger powder on the mayonnaise oxidative stability, rheological measurements, and sensory characteristics. Annals of Agricultural Science, v. 58, n. 2, p. 213-220, 2013. http://dx.doi.org/10.1016/j.aoas.2013.07.016. 
Enhancing the quality attributes of salad dressing by incorporating Gac aril as a biologically active ingredient Naknaen, $P$. et al.

KONG, K. W.; ISMAIL, A. Lycopene content and lipophilic antioxidant capacity of by-products from Psidium guajava fruits produced during puree production industry. Food and Bioproducts Processing, v. 89, n. 1, p. 53-61, 2011. http:// dx.doi.org/10.1016/j.fbp.2010.02.004.

KUBOLA, J.; SIRIAMORNPUN, S. Phytochemicals and antioxidant activity of different fruit fractions (peel, pulp, aril and seed) of Thai gac (Momordica cochinchinensis Spreng). Food Chemistry, v. 127, n. 3, p. 1138-1145, 2011. http://dx.doi.org/10.1016/j. foodchem.2011.01.115. PMid:25214106.

KWON, K.; KO, J. H.; SHIN, H. S. Evaluation of antioxidant activity of oxidative stability of spice-added mayonnaise. Food Science and Biotechnology, v. 24, n. 4, p. 1285-1292, 2015. http://dx.doi.org/10.1007/s10068-015-0165-1.

LATIMER JUNIOR, G. W. (Ed.). Official methods of analysis of the Association of Official Analytical Chemists. 19th ed. Gaithersburg: AOAC International, 2012.

LI, C.-Y.; KIM, H.-W.; LI, H.; LEE, D.-C.; RHEE, H.-I. Antioxidant effect of purple corn extracts during storage of mayonnaise. Food Chemistry, v. 152, p. 592-596, 2014. http://dx.doi.org/10.1016/j. foodchem.2013.11.152. PMid:24444980.

MAQSOOD, S.; BENJAKUL, S. Comparative studies of four different phenolic compounds on in vitro antioxidative activity and the preventive effect on lipid oxidation of fish oil emulsion and fish mince. Food Chemistry, v. 119, n. 1, p. 123-132, 2010. http://dx.doi.org/10.1016/j.foodchem.2009.06.004.

MCCLEMENTS, D. J.; DECKER, E. A. Lipid oxidation in oil-in-water emulsions: Impact of molecular environment on chemical reactions in heterogeneous food systems. Journal of Food Science, v. 65, n. 8, p. 1270-1282, 2000. http://dx.doi. org/10.1111/j.1365-2621.2000.tb10596.x

MELO, A. N. F.; SOUZA, E. L.; ARAUJO, V. B. S.; MAGNANI, M. Stability, nutritional and sensory characteristics of French salad dressing made with manoprotein from spent brewer's yeast. Lebensmittel-Wissenschaft + Technologie, v. 62, n. 1, p. 771-774, 2015. http://dx.doi.org/10.1016/j.Iwt.2014.06.050.

O'KEEFE, S. F.; PIKE, O. A. Fat characterization. In: NIELSEN, S. S. (Ed.). Food analysis. New York: Springer Science \& Business Media, 2010. http://dx.doi.org/10.1007/978-1-4419-1478-1_14.

RADFORD, S. A.; BOARD, R. G. Review: fate of pathogens in homemade mayonnaise and related products. Food Microbiology, $v$. 10, n. 4, p. 269-278, 1993. http://dx.doi.org/10.1006/fmic.1993.1031.
SANGKASANYA, S.; PHITUKCHEEPCHAROEN, S.; NAKPHANOM, C.; NAKNAEN, P. Red aril and yellow pulp from Gac fruit (Momordica cochinchinensis Spreng) as a source of biologically active ingredients for functional drink: effect of formulation. In: FOOD INNOVATION ASIA CONFERENCE 2016 (FIAC 2016), 18., 2016, Thailand. Proceedings... Bangkok: FIAC, 2016. p. 215-222.

SANTIPANICHWONG, R.; SUPHANTHARIKA, M. Carotenoids as colorants in reduced-fat mayonnaise containing spent brewer's yeast $\beta$-glucan as a fat replacer. Food Hydrocolloids, v. 21, n. 4 , p. 565-574, 2007. http://dx.doi.org/10.1016/j.foodhyd.2006.07.003.

SHANTHA, N. C.; DECKER, E. A. Rapid, sensitive, iron-based spectrophotometric methods for determination of peroxide values of food lipids. Journal of AOAC International, v. 77, n. 2, p. 421-424, 1994. PMid:8199478.

SHI, J.; DAI, Y.; KAKUDA, Y.; MITTAL, G.; XUE, S. J. Effect of heating and exposure to light on the stability of lycopene in tomato puree. Food Control, v. 19, n. 5, p. 514-520, 2008. http:// dx.doi.org/10.1016/j.foodcont.2007.06.002.

SIWACH, R.; TOKAS, J.; SETH, R. Use lycopene as a natural antioxidant in extending the shelf-life of anhydrous cow milk fat. Food Chemistry, v. 199, p. 541-546, 2016. http://dx.doi. org/10.1016/j.foodchem.2015.12.009. PMid:26776006.

TSENG, A.; ZHAO, Y. Wine grape pomace as antioxidant dietary fiber for enhancing nutritional value and improving storability of yogurt and salad dressing. Food Chemistry, v. 138, n. 1, p. 356-365, 2013. http://dx.doi.org/10.1016/j.foodchem.2012.09.148. PMid:23265499

VUONG, L. T.; FRANKE, A. A.; CUSTER, L. J.; MURPHY, S. P. Momordica cochinchinensis Spreng. (gac) fruit carotenoids reevaluated. Journal of Food Composition and Analysis, v. 19, n. 6-7, p. 664-668, 2006. http://dx.doi.org/10.1016/j. jfca.2005.02.001.

WORRASINCHAI, S.; SUPHANTHARIKA, M.; PINJAI, S.; JAMNONG, P. $\beta$-Glucan prepared from spent brewer's yeast as a fat replacer in mayonnaise. Food Hydrocolloids, v. 20, n. 1, p. 68-78, 2006. http://dx.doi.org/10.1016/j.foodhyd.2005.03.005.

ZOU, L.; AKOH, C. C. Characterization and optimization of physical and oxidative stability of structured lipid-based infant formula emulsion: effects of emulsifiers and biopolymer thickeners. Food Chemistry, v. 141, n. 3, p. 2486-2494, 2013. http://dx. doi. org/10.1016/j.foodchem.2013.05.029. PMid:23870985. 